\title{
ORGANIC PRODUCTION OF TOMATOES IN THE AMAZON REGION BY PLANTS GRAFTED ON WILD Solanum ROOTSTOCKS
}

\author{
Produção orgânica de tomates na região amazônica por \\ tomateiros enxertados em espécies selvagens de Solanum \\ Elaine Aparecida de Paula Farias ${ }^{1}$, Regina Lúcia Félix Ferreira ${ }^{1}$, \\ Sebastião Elviro de Araújo Neto ${ }^{2}$, Fabiana Cruz Costa', Damaris Suelen Nascimento ${ }^{1}$
}

\begin{abstract}
The production of organically grown tomatoes in the Amazonian region of Brazil is difficult due to inherent phytosanitary issues. The objectives of the present investigation were to evaluate the productivity of grafted tomato plants (Solanum lycopersicum cv. Santa Adélia) grown organically in Rio Branco, Acre, Brazil, and to assess scion/rootstock compatibility under organic growth conditions. The Solanum species employed as rootstocks were $S$. gilo (jiló), S. lycocarpum (jurubebão), S. stramonifolium (jurubeba vermelha) and $S$. viarum (joá), while the susceptible $S$. lycopersicum cultivar Santa Adélia was the scion. Ungrafted tomato plants and tomato grafted on tomato rootstock were employed as controls. The experiment was arranged in a completely randomized block design with six treatments and five repetitions of five plants each. Data were submitted to analysis of variance and the significance of differences between treatments were determined using the Tukey test $(P<0.05)$. All ungrafted tomato plants and those comprising tomato grafted on $S$. lycopersicum rootstock became infected by brown rot and perished. The total numbers of fruits, numbers of marketable fruits, mean masses of fruits, total productivities and productivities of marketable fruits associated with tomato grafted on $S$. gilo, S. lycocarpum and $S$. stramonifolium rootstocks were significantly higher $(P<0.05)$ than the equivalent values obtained with tomato grafted on $S$. viarum rootstock. $S$. gilo exhibited the best compatibility index (1.11) of all rootstock/scion combinations studied. It is concluded that tomato grafted on S. gilo, S. lycocarpum and S. stramonifolium rootstocks represent viable alternatives for the production of organic tomatoes in the Amazon region.
\end{abstract}

Index terms: Organic farming, grafting, productivity

\section{RESUMO}

A produção de tomates, por meio de sistemas orgânicos, na região amazônica, é difícil, decorrente aos inerentes problemas fitossanitários. Objetivou-se, na presente investigação, avaliar a produtividade de tomateiros (Solanum lycopersicum cv. Santa Adélia) enxertados e cultivados segundo o sistema orgânico em Rio Branco, Acre, Brasil, assim como avaliar a compatibilidade enxerto/porta-enxerto sob as mesmas condições. As espécies de Solanum utilizadas como porta-enxerto foram S. gilo (jiló), $S$. lycocarpum (jurubebão), S. stramonifolium (jurubeba vermelha) e $S$. viarum (joá). Tomateiros pés-francos e tomateiros autoenxertados foram usados como controles. O delineamento experimental consistiu de blocos ao acaso, com seis tratamentos e cinco repetições de cinco plantas cada. Os dados foram submetidos à análise de variância e as diferenças significativas entre os resultados foram determinadas por meio do teste de Tukey $(P<0,05)$. Os tomateiros pés-francos e os tomateiros autoenxertados foram afetados pela murcha bacteriana e pereceram. O número total de frutos, número de frutos comerciais, massa média dos frutos, produtividade total e produtividade comercial dos tomateiros enxertados em S. gilo, S. lycocarpum and S. stramonifolium foram significativamente maiores $(P<0.05)$ do que a dos tomateiros enxertados em $S$. viarum. O porta-enxerto $S$. gilo exibiu o melhor índice de compatibilidade $(1,11)$ entre todas as combinações enxerto/porta-enxerto estudadas. Conclui-se que os tomateiros enxertados em S. gilo, S. lycocarpum e $S$. stramonifolium representam alternativas viáveis para a produção orgânica de tomates na região amazônica.

Termos para indexação: Agricultura orgânica, enxertia, produtividade.

(Received in january 24, 2013 and approved in june 26, 2013)

\section{INTRODUCTION}

Tomato (Solanum lycopersicum L.) is economically one of the most important horticultural crops worldwide. The fruit represents an important dietary source of vitamins and minerals since it can be consumed in natura, incorporated into numerous recipes or ingested in processed forms (sauces, ketchup, chutney, etc).

Tomatoes are cultivated in the field and in greenhouses over a wide range of latitudes using many different technologies (PEREIRA et al., 2012). In the Amazon region of Brazil, however, tomato cultivation is

'Universidade Federal do Acre/UFAC - Centro de Ciências Biológicas e da Natureza - Rio Branco - AC - Brasil

2Universidade Federal do Acre/UFAC - Centro de Ciências Biológicas e da Natureza - BR 364 - Km 04 - $69920-200$ - Rio Branco - AC - Brasil selviro2000@yahoo.com.br 
currently restricted mainly to the states of Amazonas (919 $\mathrm{t}$ year $\left.{ }^{-1}\right)$ and Roraima $\left(5388 \mathrm{t} \mathrm{year}^{-1}\right)$. Such yields, which represent just 0.02 and $0.13 \%$, respectively, of the national production of Brazil (ANUÁRIO DA AGRICULTURA BRASILEIRA-AGRIANUAL, 2012), are insufficient to meet local demands and the region is, to a large extent, dependent on imports from other states.

One of the principal factors limiting the expansion of tomato cultivation in the Amazon region is the incidence of brown rot, a disease caused by the soil borne bacterial pathogen Ralstonia solanacearum (Smith) Yabuuchi (PENA et al., 2010), which can give rise to devastating losses (up to $100 \%$ ) in production. Additionally, the increasing pressure by consumers for healthier foods containing lower levels of chemical and microbial residues has stimulated tomato growers to switch from conventional farming to systems employing clean technologies (MELO et al., 2009; LIMA; MOREIRA; PINTO, 2011). Unfortunately, the production of tomatoes by organic farming in tropical regions is challenging because of the inherent phytosanitary issues associated with this culture (SCHALLENBERGERet al., 2008).

Enhancement of resistance to brown rot in susceptible tomato cultivars can be achieved by grafting on disease resistant rootstocks (CARDOSO et al., 2006). In contrast to traditional methods of disease management involving, for example, fumigation with methyl bromide, grafting technology is not only efficient but is also environmentally clean (GONZALES et al., 2008). Grafting is employed widely in the cultivation of members of the families Solanaceae (tomato, eggplant and pepper) and Cucurbitaceae (cucumber, melon and watermelon) (CAÑIZARES; GOTO, 2002; SANTOS; GOTO, 2004; CARDOSO et al., 2006) in order to confer resistance to low temperature, drought and excessive humidity, and to augment nutritional value (PEIL, 2003; CANTU et al., 2009a; KING et al., 2010). In the case of tomato, the yield and quality of the fruit is highly dependent on the type of rootstock employed (CARDOSO et al., 2006; FLORES et al., 2010), which may serve to increase the capacity of the scion to uptake water and nutrients and, consequently, to accumulate increased biomass (TOMAZ et al., 2006; AULER; FLORI-TUTIDA; TAZIMA2008).

The objectives of the present investigation were: (i) to evaluate the productivity of organically grown grafted tomato plants, and (ii) to assess scion/rootstock compatibility under organic growth conditions.

\section{MATERIALS AND METHODS}

The experiment was conducted at the Sítio Ecológico Seridó, Rio Branco, Acre, Brazil (953'16" S, 67\%49'11' W; $150 \mathrm{~m}$ altitude) during April-October 2011. According to the Köppen classification, the region presents a tropical moist climate (Am) with a mean temperature of $24.5^{\circ} \mathrm{C}$, relative humidity of $84 \%$ and annual precipitation in the range 1700 and $2400 \mathrm{~mm}$. The soil is categorized as yellow clay with plinthite (Argissolo Amarelo Alítico Plíntico) according to the Brazilian Soil Classification System (EMPRESA BRASILEIRA DE PESQUISA AGROPECUÁRIA-EMBRAPA, 2006). Chemical analysis of horizon $\mathrm{A}(0-20 \mathrm{~cm})$ revealed the following characteristics: $\mathrm{pH} 5.6$; organic matter $51.3 \mathrm{~g}$ $\mathrm{dm}^{-3}$; P $256.5 \mathrm{mg} \mathrm{dm}^{-3} ; \mathrm{K} 8.1 \mathrm{mmol}_{\mathrm{c}} \mathrm{dm}^{-3} ; \mathrm{Ca}^{-3} 7.5 \mathrm{mmol}_{\mathrm{c}}$ $\mathrm{dm}^{-3} ; \mathrm{Mg} 58 \mathrm{mmol} \mathrm{dm}_{\mathrm{c}}^{-3} ; \mathrm{Al} 0.00 \mathrm{mmol}_{\mathrm{c}} \mathrm{dm}^{-3} ; \mathrm{H}+\mathrm{Al} 28.5^{\mathrm{c}}$ $\mathrm{mmol}_{\mathrm{c}} \mathrm{dm}^{-3}$; sum of bases $153.6 \mathrm{mmol}_{\mathrm{c}} \mathrm{dm}^{-3}$; cation exchange capacity $182.1 \mathrm{mmol}_{\mathrm{c}} \mathrm{dm}^{-3}$; base saturation $84.35 \%$; $\mathrm{Ca} / \mathrm{Mg}$ ratio 1.52 ; and $\mathrm{Mg} / \mathrm{K}$ ratio 8.13. Beds for the cultivation of grafted tomato plants were prepared in an area that had previously been ploughed with a moldboard plow, tilled with an animal-driven harrow comprising five blades and six discs, and concomitantly fertilized with $1.0 \mathrm{t} \mathrm{ha}^{-1}$ of dolomitic limestone, $1.0 \mathrm{tha}^{-1}$ of phosphate and $15 \mathrm{t} \mathrm{ha}^{-1}$ of organic compost (dry base). The cultivation beds were covered with double-sided (black/white) plastic sheeting perforated at $0.90 \times 0.60 \mathrm{~m}$ spacings.

Four species of Solanum were employed as rootstocks, namely, S. gilo Raddi (jiló), S. lycocarpum A. St. -Hil. (jurubebão), S. stramonifolium Jacq. (jurubeba vermelha) and $S$. viarum Dunal (joá), while $S$. lycopersicum L. cv. Santa Adélia was used as scion. These species were selected because they are well adapted to the Amazon region and have not been found in nature with brown rot, although there is no reference in the literature regarding resistance to this disease. Literature on the botanical characteristics of these Solanum species is rather old (more than 10 years). Ungrafted tomato plants and tomato scion grafted on tomato rootstock were used as controls.

Seeds were sown in 128-cell polystyrene trays containing substrate [soil, organic compost, burnt rice husks (1:1:1) plus $10 \%$ powdered charcoal] supplemented with thermophosphate $\left(1.5 \mathrm{~kg} \mathrm{~m}^{-3}\right)$ and lime $\left(1.0 \mathrm{~kg} \mathrm{~m}^{-3}\right)$ on the $2^{\text {nd }}$ April 2011 for rootstocks and on the $4^{\text {th }}$ May 2011 for the scion. Rootstock plantlets were transferred to plastic pots $(180 \mathrm{~mL})$ on $14^{\text {th }}$ May 2011. Cleft grafting was performed on $4^{\text {th }}$ June 2011 when rootstock plants presented five to six true leaves and scions presented three 
to four true leaves. The grafting technique involved slicing the rootstock stem with a steel razor blade at a position above the second true leaf and opening a $1.5 \mathrm{~cm}$ deep cleft across the diameter of the stem. The scion stem was cut to a V-shaped wedge just above the cotyledonary leaves leaving three to four young leaves. The base of each scion was then inserted into the cleft of the rootstock and the whole clamped together with a grafting clip that could be readily removed after the emergence of shoots without causing injury to the grafted plants.

Grafted plants and ungrafted controls were maintained in a moist chamber for 13 days before being transferred to the cultivation beds. Plants were cultivated under a chapel-type greenhouse ( $30 \mathrm{~m}$ long; $4.60 \mathrm{~m}$ wide; $3.70 \mathrm{~m}$ central height; $1.80 \mathrm{~m}$ wall height) covered with transparent polyethylene sheet (150 $\mu \mathrm{m}$ thickness) but with open sides. Each plant was supported by two stakes and trellised with wire and cord. Drip irrigation was supplied through a tubing system that provided a daily average of $6 \mathrm{~mm}$ of water. Lateral branches were pruned as they appeared. Preventive treatment against fungal diseases of the aerial parts comprised three applications of $4 \%$ lime sulfur, once 10 days before flowering and twice after flowering within an interval of 15 days. Simultaneously, three spray applications of $1 \%$ neem oil were carried out with the purpose of controlling infestation by aphids and white fly. Aliquots $(200 \mathrm{~mL})$ of the anaerobic biofertilizer Supermagro $(0.10 \% \mathrm{~N}, 0.06 \% \mathrm{P}$, $0.06 \% \mathrm{~K}, 0.13 \% \mathrm{Ca}, 0.12 \% \mathrm{Mg}, 0.11 \% \mathrm{~S}, 0.04 \% \mathrm{Fe}, 0.01 \%$ $\mathrm{Mn}, 0.02 \% \mathrm{Cu}, 27.5 \% \mathrm{Zn}, 0.15 \% \mathrm{~B}, 0.09 \mathrm{Na}, 0.02 \% \mathrm{Mo}$, $0.01 \% \mathrm{Al}$ ) developed at the Instituto Campineiro de Análise de Solos e Adubo (ICASA, Campinas, SP, Brazil) were applied to plants weekly from the time of transfer to the cultivation beds until flowering. As the fruits became mature, i.e. when 10 to $30 \%$ of the fruit surface exhibited a red color, they were harvested and separated according to the directives of the Ministry of Agriculture, Provisioning and Land Reform (MINISTÉRIO DE AGRICULTURA, ABASTECIMENTO E REFORMA AGRÁRIA, 1995). Fruits of marketable quality exhibited a diameter $>40 \mathrm{~mm}$ and were free from major defects while all other fruits were considered rejects. Following selection, fruits in both groups were counted, weighed and their diameters measured using a digital pachymeter. A total of 17 harvestings of the fruits were carried out during the experimental period.

The parameters evaluated during the study were: diameter of rootstocks ( $\mathrm{mm})$, diameter of scions $(\mathrm{mm})$, scion/rootstock compatibility index, total number of fruits per plant, number of marketable fruits per plant, number of rejected fruits per plant, total mass of fruits $\left(\mathrm{kg} \mathrm{plant}^{-1}\right)$, total mass of marketable fruits $\left(\mathrm{kg} \mathrm{plant}^{-1}\right)$, mean mass of fruits ( $\mathrm{g}$ fruit $\left.\mathrm{t}^{-1}\right)$, mean mass of marketable fruits $\left(\mathrm{g}\right.$ fruit $\left.{ }^{-1}\right)$ and mean mass of rejected fruits $(\mathrm{g}$ fruit $\left.^{-1}\right)$. The diameters of rootstocks and scions were measured at points $2 \mathrm{~cm}$ below and $2 \mathrm{~cm}$ above the graft, respectively, using a digital pachymeter. The rootstock/scion compatibility index was determined from the ratio of the diameter of the rootstock to that of the scion. The productivity $\left(\mathrm{kg} \mathrm{ha}^{-1}\right)$ that could be attained by a commercial operation conducted using the experimental conditions described was estimated from the equation:

Productivity $=12962$ plants ha ${ }^{-1} \mathrm{x}$ total mass of marketable fruits $\left(\mathrm{kg} \mathrm{plant}^{-1}\right)$

The experiment was arranged in a completely randomized block design with six treatments and five repetitions of five plants each. Data were submitted to analysis of variance (ANOVA) and the significance of differences between treatments was determined using the Tukey test at $5 \%$ probability.

\section{RESULTS AND DISCUSSION}

All of the ungrafted tomato plants and those comprising tomato grafted on S. lycopersicum rootstock became infected by $R$. solanacearum and, subsequently, perished. The occurrence of brown rot disease was confirmed by the observation of a milky bacterial stream (strands) flowing from the lower cut surface of a thin slice of infected stem that had been placed on the inside of a beaker of water at the water level. Statistical analyses could be applied only to tomato scions grafted on $S$. gilo, S. lycocarpum, S. stramonifolium and S. viarum rootstocks, since $100 \%$ of the plants were unaffected by brown rot.

The diameters of $S$. gilo and S. lycocarpum rootstocks in fully developed grafted plants were significantly larger in comparison with those of $S$. stramonifolium and $S$. viarum (Table 1). It is possible that the growth of $S$. gilo and $S$. lycocarpum rootstocks and their tomato scions were more synchronized than in the other grafts, resulting in superior (i.e. closer to unity) compatibility indexes. However, although the diameter of $S$. stramonifolium rootstock was smaller than those of $S$. gilo and $S$. lycocarpum, and the compatibility with the scion was inferior, the diameter attained by the scion was similar to those observed in S. gilo and S. lycocarpum- 
grafted plants. The greater productivity presented by tomato grafted on $S$. gilo, $S$. lycocarpum and $S$. stramonifolium rootstocks can be explained on the basis of their vigor, as determined by the diameter of the scion. The compatibility between rootstock and scion derives from morphological, anatomical and histological affinity of the pair whereby the xylem and phloem vessels of the joining plants are similar in number and diameter (PEIL, 2003). The degree of compatibility between rootstock and scion influences the exchange of resources (water, carbohydrates, minerals, growth regulator messengers, etc) and, to some extent, affects the relationship of the pair.

As shown in table 2, the total number of fruits and the number of marketable fruits produced by grafts involving S. gilo, S. lycocarpum and S. stramonifolium rootstocks were significantly higher than those produced by grafts on S. viarum rootstock. On the other hand, there were no significant differences between the grafts regarding the number of rejected fruits, independent of the rootstock involved. Cardoso et al., (2006) evaluated the feasibility of using the tomato hybrid Hawaii 7996 as rootstock and found that the total number of tomatoes per plant varied between 40.6 and 64.2 , values that were similar to those obtained in the present study. The increased yield conferred by some rootstocks to grafted tomato plants may be associated with an increase in nutrient uptake and the consequent improvement in biomass accumulation (TOMAZet al., 2006).

Tomato grafted on S. viarum rootstock produced fruits with significantly smaller mean mass in comparison with grafts involving other Solanum rootstocks (Table 2). As a consequence, the overall productivity of $S$. viarum grafts was very much (up to 73\%) lower than those of the other grafted plants (Table 3). In contrast, the total productivities as well as the yields of marketable tomatoes conferred by S. gilo, S. lycocarpum and S. stramonifolium rootstocks were similar. The lower productivity of tomato grafted on $S$. viarum rootstock was probably due to poor plant vigor, i.e. the rootstocks developed less than the scions. This phenomenon has been observed by Auler, Flori-Tutida and Tazima (2008) when orange tree cv. Valencia was grafted on different citrus rootstocks. In this case, the growth of the scions and their capacity to absorb water and to take up nutrients was affected significantly by the rootstocks.

Table 1 - Diameters and compatibilities of rootstocks and scions in plants with Solanum lycopersicum cv. Santa Adélia grafted on different Solanum spp.

\begin{tabular}{lccc}
\hline Rootstock & Diameter of rootstocks $(\mathrm{mm})$ & $\begin{array}{c}\text { Diameter of scions } \\
(\mathrm{mm})\end{array}$ & \begin{tabular}{c} 
Compatibility index \\
\hline S. gilo $^{*}$
\end{tabular} lycocarpum $^{\#}$ \\
S. stramonifolium $^{\dagger}$ & $15.34^{\mathrm{a}}$ & $19.42^{\mathrm{ab}}$ & $1.11^{\mathrm{d}}$ \\
${\text { S. } \text { viarum }^{\ddagger}}_{\text {Coefficient }^{\mathrm{a}} \text { of variance }}^{15.15^{\mathrm{a}}}$ & $10.32^{\mathrm{b}}$ & $19.32^{\mathrm{ab}}$ & $1.15^{\mathrm{c}}$ \\
\hline
\end{tabular}

Within each column, mean values followed by dissimilar superscript letters are significantly different according to the Tukey test at $5 \%$ probability. Common names of Solanum spp.: *jiló, " jurubebão, "jurubeba vermelha and "joá.

Table 2 - Number and biomass of fruits produced by grafted plants with Solanum lycopersicum cv. Santa Adélia as scion and different Solanum spp. as rootstock.

\begin{tabular}{|c|c|c|c|c|c|}
\hline Rootstock & $\begin{array}{l}\text { Total no. } \\
\text { of fruits } \\
\left.\text { (plant }^{-1}\right)\end{array}$ & $\begin{array}{l}\text { No. of marketable } \\
\text { fruits } \\
\left.\text { (plant }^{-1}\right)\end{array}$ & $\begin{array}{c}\text { No. of } \\
\text { rejected fruits } \\
\left.\text { (plant }^{-1}\right)\end{array}$ & $\begin{array}{c}\text { Mean mass of } \\
\text { fruits } \\
\left(\mathrm{g} \text { fruit }{ }^{-1}\right)\end{array}$ & $\begin{array}{l}\text { Mean mass of } \\
\text { marketable fruits } \\
\left(\mathrm{g} \text { fruit }{ }^{-1}\right)\end{array}$ \\
\hline S. gilo* & $57.4^{\mathrm{a}}$ & $44.0^{\mathrm{a}}$ & $13.4^{\mathrm{a}}$ & $80.02^{\mathrm{ab}}$ & $82.24^{\mathrm{ab}}$ \\
\hline S. lycocarpum ${ }^{\#}$ & $49.0^{\mathrm{a}}$ & $34.0^{\mathrm{a}}$ & $15.0^{\mathrm{a}}$ & $93.80^{\mathrm{a}}$ & $97.93^{\mathrm{a}}$ \\
\hline S. stramonifolium ${ }^{\dagger}$ & $49.8^{\mathrm{a}}$ & $39.8^{\mathrm{a}}$ & $10.0^{\mathrm{a}}$ & $94.58^{\mathrm{a}}$ & $95.35^{\mathrm{a}}$ \\
\hline S. viarum ${ }^{*}$ & $20.5^{\mathrm{b}}$ & $15.2^{\mathrm{b}}$ & $5.3^{\mathrm{a}}$ & $61.48^{\mathrm{b}}$ & $62.87^{\mathrm{b}}$ \\
\hline Coefficient of variance & 15.3 & 18.8 & 33.3 & 4.92 & 4.57 \\
\hline
\end{tabular}

Within each column, mean values followed by dissimilar superscript letters are significantly different according to the Tukey test at $5 \%$ probability. Common names of Solanum spp.: *jiló, " jurubebão, ‘jurubeba vermelha and "joá. 
Table 3 - Production of fruit by grafted plants with Solanum lycopersicum cv. Santa Adélia as scion and different Solanum spp. as rootstock.

\begin{tabular}{|c|c|c|c|c|}
\hline Rootstock & $\begin{array}{c}\text { Total } \\
\text { productivity } \\
\left(\mathrm{kg} \mathrm{plant}^{-1}\right)\end{array}$ & $\begin{array}{c}\text { Productivity of marketable } \\
\text { fruits } \\
\left(\mathrm{kg} \mathrm{plant}^{-1}\right)\end{array}$ & $\begin{array}{l}\text { Productivity of } \\
\text { rejected fruits } \\
\left(\mathrm{kg} \mathrm{plant}^{-1}\right)\end{array}$ & $\begin{array}{l}\text { Commercial } \\
\text { productivity } \\
\left(\mathrm{t} \mathrm{ha}^{-1}\right)\end{array}$ \\
\hline S. gilo* & $4.565^{\mathrm{a}}$ & $3.530^{\mathrm{a}}$ & $0.921^{\mathrm{ab}}$ & $45,750^{\mathrm{a}}$ \\
\hline S. lycocarpum ${ }^{\#}$ & $4.611^{\mathrm{a}}$ & $3.334^{\mathrm{a}}$ & $1.214^{\mathrm{a}}$ & $43,229^{\mathrm{a}}$ \\
\hline S. stramonifolium ${ }^{\dagger}$ & $4.700^{\mathrm{a}}$ & $3.862^{\mathrm{a}}$ & $0.593^{\mathrm{ab}}$ & $50,061^{\mathrm{a}}$ \\
\hline S. viarum ${ }^{\ddagger}$ & $1.304^{\mathrm{b}}$ & $1.037^{\mathrm{b}}$ & $0.239^{\mathrm{b}}$ & $13,441^{\mathrm{b}}$ \\
\hline Coefficient of variance & 4.59 & 6.71 & 40.51 & 5.03 \\
\hline
\end{tabular}

Within each column, mean values followed by dissimilar superscript letters are significantly different according to the Tukey test at $5 \%$ probability. Common names of Solanum spp.: *jiló, \# jurubebão, ‘jurubeba vermelha and *joá.

The results obtained in the present study were within the ranges reported by Melo et al. (2009) for the mass of marketable fruits (63.2 to $123.3 \mathrm{~g}$ fruit $^{-1}$ ) and for total productivity $\left(2.183-5.563 \mathrm{~kg}\right.$ plant $\left.^{-1}\right)$. Moreover, the yields of marketable fruits produced by tomato grafted on S. gilo, S. lycocarpum and S. stramonifolium rootstocks were within the range (equivalent to $3.82-$ $5.66 \mathrm{~kg} \mathrm{plant}^{-1}$ ) reported by Cantu, Junglaus and Goto (2009b).

Lopes and Goto (2003) evaluated the productivity of the tomato cultivar Momotaro T-93 grafted on nematoderesistant tomato rootstocks Kaguemusha and Anchor T, and reported mean yields (4.85 and $5.06 \mathrm{~kg} \mathrm{plant}^{-1}$, respectively) that were significantly higher than that of ungrafted plants $\left(4.27 \mathrm{~kg} \mathrm{plant}^{-1}\right)$. However, these authors pointed out that grafting reduced the mean fruit mass from $193.95 \mathrm{~g}$ fruit $^{-1}$ in the ungrafted plants to $173.92 \mathrm{~g}$ fruit $^{-1}$ with Kaguemusha rootstock and to $180.95 \mathrm{~g}_{\text {fruit }}{ }^{-1}$ with Anchor T rootstock.

Regarding fruits that were considered to be of nonmarketable quality, the largest yield of rejected fruit was obtained with $S$. lycocarpum rootstock while the lowest was with $S$. viarum grafts. This finding may be explained by the formation by $S$. viarum-grafted plants of smaller sized fruits that required fewer nutrients, and by the presence of apical rotting observed in the larger fruits formed by $S$. lycocarpum-grafted plants. It is known that different rootstocks may induce alterations in the morphological and physiological characteristics of the aerial parts of grafted plants caused by modifications in root growth, absorption and translocation of essential minerals, particularly under stress conditions such as those incurred in the present study (GOTO; SANTOS; CAÑIZARES, 2003, SCHWARZ et al., 2013).

The estimated commercial productivities of the studied grafted tomato plants were comparable with that reported for conventional tomato crops in Brazil (55 tha-1; CANÇADO-JÚNIOR et al., 2003), but very much lower than the productivity of the cultivar Carmen $\left(77 \mathrm{t} \mathrm{ha}^{-1}\right)$ when grown in a protected environment (MARQUES; TIBOLA; PRIEBE, 2000). However, productivity is not considered a major issue in organic tomato farming, and lower yields are somewhat expected (CARDOSO et al., 2006). Of crucial importance is the quality of the organic product (SILVA et al., 2011).

\section{CONCLUSION}

Tomato grafted on the disease-resistant rootstocks, S. gilo, S. lycocarpum and S. stramonifolium, could represent excellent alternatives for application in organic farming in the Amazonian region of Brazil.

\section{ACKNOWLEDGEMENTS}

The authors wish to thank Coordenação de Aperfeiçoamento de Pessoal de Nível Superior (CAPES) for the grant awarded to the first author.

\section{REFERENCES}

\section{ANUÁRIO DA AGRICULTURABRASILEIRA- AGRIANUAL. Produção de frutas no Brasil. São Paulo: FNP Consultoria, 2012.}

AULER, P.A.M.; FIORI-TUTIDA, A.C.G.; TAZIMA, Z.H. Comportamento da laranjeira 'Valência' sobre seis porta-enxertos no noroeste do Paraná. Revista

Brasileira de Fruticultura, Jaboticabal, v.30, n.1, p.229-234, mar., 2008.

CANTU, R.R. et al. Reação de porta-enxertos comerciais de tomateiro a Meloidogyne mayaguensis. Summa Phytopathológica, Botucatu, v.35, n.3, p.216-218, jul/sep., 2009a. 
CANTU, R.R.; JUNGLAUS, R.W.; GOTO, R.

Produtividade e crescimento do tomateiro 'Paron' enxertado em diferentes porta-enxertos. Agropecuária Catarinense, Florianópolis, v.22, n.1, p.67-71, Jan-Feb, 2009b.

CANÇADO-JÚNIOR, F.L. et al. Aspectos econômicos da produção e comercialização do tomate para a mesa. Informe Agropecuário, Belo Horizonte, v.219, n.24, p.7$18,2003$.

CAÑIZARES, K.A.L.; GOTO, R. Comparação de métodos de enxertia em pepino. Horticultura Brasileira, Brasília, v.20, n.1, p. 95-99, mar., 2002.

CARDOSO, S.C. et al. Viabilidade de uso do híbrido Hawaii 7996 como porta-enxerto de cultivares comerciais de tomate. Bragantia, Campinas, v.65, n.1, p.89-96, 2006.

EMPRESA BRASILEIRA DE PESQUISA AGROPECUÁRIA- EMBRAPA. Centro Nacional de Pesquisa de Solos. Sistema brasileiro de classificação de solos. 2.ed. Rio de Janeiro, 2006, 306p.

FLORES, F.B. et al. The effectiveness of grafting to improve tomato fruit quality. Scientia Horticulturae, Amsterdam, v.125, n.3 p.211-217, jun., 2010.

GONZALES, F.M. et al. El injerto herbáceo: alternativa para el manejo de plagas del suelo. Revista Protección Vegetal, La Habana, v.23, n.2, p. 69-74, may/aug., 2008.

GOTO, R.; SANTOS, H.S.; CAÑIZARES, K.A.L. Enxertia em hortaliças. São Paulo: Editora UNESP, 2003.

KING, S.R. et al. Genetics, breeding and selection of rootstocks for Solanaceae and Curcurbitaceae. Scientia Horticulturae, Amsterdam, v.127, n.2, p.106-111, dec., 2010.

LIMA, B.M.F.V.; MOREIRA, J.O.T.; PINTO, H.C. do S. Avaliação de extratos vegetais no controle de mosca branca em tomate. Revista Caatinga, Mossoró, v.24, n.4, p.36-42, oct/dec., 2011.

LOPES, M.C.; GOTO, R. Produção do híbrido Momotaro de tomateiro, em função da enxertia e do estádio das mudas no plantio. Horticultura Brasileira, Brasília, v.21, n.3, p.553-557, jul/sep., 2003.
MARQUES, F.C.; TIBOLA, A.J.; PRIEBE, A.J. Cultivo protegido de cultivares de tomateiro submetidas ou não a desbrota. Horticultura Brasileira, Brasília, v.18, p.190191, jul., 2000.

MELO, P.C.T. et al. Desempenho de cultivares e tomateiro em sistema orgânico sob o cultivo protegido. Horticultura Brasileira, Brasília, v.27, n.4, p.553-559, oct/dec., 2009.

\section{MINISTÉRIODE AGRICULTURA, ABASTECIMENTO E REFORMA AGRÁRIA. Portaria n553, de 30 de agosto de 1995. Norma de identidade, qualidade, acondicionamento e embalagem do tomate. Brasília: Ministério de Agricultura, Abastecimento e Reforma Agrária. Available at: <http://www.codapar.pr.gov.br/ arquivos/File/pdf/tomate.pdf> Accessed on: $26 \mathrm{dec}$. 2012.}

PEIL, R.M. A enxertia na produção de mudas de hortaliças. Ciência Rural, Santa Maria, v.33, n.5, p.11691177, nov/dec., 2003.

PENA, M.A.A. et al. Adaptabilidade e estabilidade de genótipos de tomateiro sob cultivo em solos de terra firme e várzea da Amazônia infestados por Ralstonia solanacearum. Bragantia, Campinas, v.69, n.1, p.27-37, 2010.

PEREIRA, M.A.B. et al. R. Adaptabilidade e estabilidade produtiva de genótipos de tomateiro em condições de temperatura elevada. Revista Ciência Agronômica, Fortaleza, v.43, n.2, p.330-337, apr/jun., 2012.

SANTOS, H.S.; GOTO, R. Enxertia em plantas de pimentão no controle da murcha de fitóftora em ambiente protegido. Horticultura Brasileira, Brasília, v.22, n.1, p.45-49, jan/mar., 2004.

SCHALLENBERGER, E. et al. Comportamento de plantas de tomateiros no sistema orgânico de produção em abrigo de cultivo com telas antiinsetos. Revista de Ciências Agroveterinárias, Lages, v.7, n.1, p.23-29, jun/ jul., 2008.

SCHWARZ, D. et al. Rootstocks can enhance tomato growth and quality characteristics at low potassium supply. Scientia Horticulturae, Amsterdam, v.149, p.7079, jan., 2013. 
SILVA, E.M.N.C.P. et al. Qualidade de alface crespa cultivada em sistema orgânico, convencional e hidropônico. Horticultura Brasileira, Brasília, v.29, n.2, p.242 - 245, apr/jun., 2011.
TOMAZ, M.A. et al. Absorção, translocação e utilização de zinco, cobre e manganês por mudas, enxertadas de Coffea arabica. Revista Brasileira de Ciência do Solo, Viçosa, v.30, n.2, p.377-384, mar/apr., 2006. 